\title{
State Jurisdiction To Tax Income From Foreign Land
}

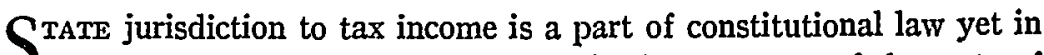
$S$ the making. Two questions are involved: the power of the state of economic origin or source to tax income flowing to a nonresident; and the power of the state of residence of the recipient to tax income from out-of-state sources. In an article appearing in recent issues of the Review there appears an analysis of the theory involved and of the decided cases. ${ }^{1}$ At the time that article was written it appeared that the power of the state of origin was clearly established, but that as to the power of the state of domicil there was some doubt. ${ }^{2}$

The most recent tangent in this field is People ex rel. Cohn v. Graves, ${ }^{\mathrm{a}}$ just decided in the United States Supreme Court. Here the relator's husband had died owning New Jersey lands and debts secured by liens on such lands. His will appointed three executors, the relator and two persons resident in New Jersey. The management of the estate was in New Jersey. By the terms of the will the relator was to receive the rents from the lands and the interest from the mortgages during the period of her widowhood. The Supreme Court treated this will as creating a legal life estate in the lands and mortgages, rather than a life interest in the income of a trust. New York as the relator's domicil, assessed and collected an income tax on the entire amount received from the New Jersey properties. Relator's application for a refund was denied by the State Tax Commission, whereupon the proceeding was removed to the New York Appellate Division. This court, voting four to one, annulled the determination of the Tax Commission and held that the income was beyond the taxing jurisdiction of New York. ${ }^{4}$ The court relied upon its prior decision in People ex rel. Pierson v. Lynch ${ }^{5}$ and upon the broad language in Senior v. Braden. ${ }^{6}$ The opinion said simply that the tax on the income from New Jersey lands was no different in effect from a tax on the land itself, and was to be judged by the same jurisdictional standard.

On appeal to the New York Court of Appeals, the Tax Commission

1 Harding, State Jurisdiction to Tax Dividends and Stock Profits to Natural Persons (1937) 25 CALIF. L. Rev. 139, 285. c. VIII.

2See, generally, Harding, Double Taxation of Property and Income (1933)

3 (March 1, 1937) 81 L. Ed. Adv. Op. 409, (1937) 85 U. of PA. L. Rev. 645.

4 People ex rel. Cohn v. Graves (1936) 246 App. Div. 335, 286 N. Y. Supp. 485.

5 (1933) 237 App. Div. 763, 263 N. Y. Supp. 259.

6 (1934) 295 U. S. 422. 
prevailed. ${ }^{7}$ The majority, in a mere memorandum, simply asserted that the tax was not in effect a tax on land. The dissenting opinion, concurred in by three judges, argued from the Pollock case ${ }^{8}$ that the tax on rents was a tax on the land itself. This reasoning was supported by Senior $v$. Braden. ${ }^{2}$ The opinion correctly stated that the income from the notes and nortgages was not to be considered as derived from land; that the legal source was the intangible debt. The interest on the debt would be taxable to the creditor at the domicil unless it appeared that the debt itself was beyond the taxing jurisdiction of that state. ${ }^{10}$ It was held that the debts had acquired a business situs in New Jersey because of the localization of the management and administration there. While Maguire v. Trefry 11 would support domiciliary taxation in such a case, the minority beheved that case to have been overruled by Senior v. Braden. The ininority thus concluded that the New York tax was bad as to both rents and interest. ${ }^{12}$

The opinion by Mr. Justice Stone, ${ }^{13}$ affirming the decision of the Court of Appeals, follows familiar paths, being substantially the same as that written in the Lawrence case. ${ }^{14}$ Nor does it differ greatly from the dissent in Senior v. Braden. He states:

"Enjoyment of the privileges of residence in the state and the attendant right to invoke the protection of its laws are inseparable from responsibility for sharing the costs of government. ... A tax measured by the net incoune of residents is an equitable method of distributing the burdens of government among those who are privileged to enjoy its benefits. The tax, which is apportioned to the ability of the taxpayer to pay it, is founded upon the protection afforded by the state to the recipient of the income in his person, in bis right to receive the income and $m$ his enjoyment of it when received. These are rights and privileges which attach to domicil within the state. To them and to the equitable distribution of the tax burden, the economic advantage realized by the receipt of income and represented by tbe power to control it, bears a direct relationship."15

At risk of being repetitious it should be pointed out that there appears to be no reason why protection of the person may support a tax neasured by income received from abroad, when it will not support a tax measured by property held abroad. There seems to be no reason why

7 People ex rel. Cohn v. Graves (1936) 271 N. Y. 353, 3 N. E. (2d) 508; (1937) 17 B. U. L. Rev. 261; (1937) 5 DUKE BAR Ass'N J. 49; (1936) 22 CoRN. L. Q. 93; (1936) 22 Iowa L. REv. 166; (1936) 23 VA. L. REv. 196; (1936) 46 YALE I. J. 148.

8 Pollock v. Farmers' Loan and Trust Co. (1895) 157 U. S. 429.

- Supra note 6. passim.

10 See HARDING, op. cit. supra note $2, \S \S 38,39,46$; Harding, op. cit. supra note 1 , 11 (1920) 253 U. S. 12.

12 In view of the broad nature of the decision with respect to rents, the details of the business situs problem are not discussed herein.

${ }^{13}$ Supra note 3. Justices Butler and McReynolds dissented.

14 Lawrence v. State Tax Commission (1932) 286 U. S. 276, 87 A. L. R. 374.

15 People ex rel. Cohn v. Graves, supra note 3 , at 411. 
protection afforded the right to receive the income can support a theory of taxation which ignores completely the question of where the income was or is to be received. This is made doubly doubtful by the cases which establish that a legal right is not subject to taxation by a state merely because the state stands ready to vindicate the right in its courts if called upon to do so. ${ }^{16}$ Nor is it clear how the protection of the enjoyment of the income sustains a theory of taxation which takes no account of where or whether the income is enjoyed. A tax theory which would support a consumption or use tax will not necessarily support an income tax. Nor can the advocate of duplicate income taxation at the domicil hide behind the shibboletl of "ability to pay." The local resident whose income has already been taxed at its out-of-state source does not have the same ability to pay the second tax, as does the local resident who pays but a single tax on the same income received from a local source. ${ }^{17}$

Mr. Justice Stone labors the point that a tax on income is not a tax on its source. The differences are obvious. He then assumes that because the taxes are different the jurisdictional base must be different. It must be remembered that there is fully as much difference between an ad valorem tax and an inheritance tax as there is between an ad valorem tax and an incoine tax. Nevertheless, the same jurisdictional requirements attach to the taxation of the ownership of property and the taxation of its transfer upon death. Discredited as the Pollock case is in its definition of "direct" taxes, it still contains a simple truth: The principal value of property is its ability to produce income. To free the taxation of income from constitutional restrictions is to nullify the practical workings of all constitutional regnlation of the taxation of the property itself.

16 Farmers Loan \& Trust Co. v. Minnesota (1930) 280 U. S. 204, 65 A. L. R. 1000; Baldwin v. Missouri (1930) 281 U. S. 586, 72 A. L. R. 1303; First National Bank v. Maine (1932) 284 U. S. 312,77 A. L. R. 1401. These cases repudiate the reasoning of Mr. Justice Holmes in Blackstone v. Miller (1903) 188 U. S. 189, and in Wheeler v. Sohner (1914) 233 U. S. 434, a reasoning quite similar to that of Mr. Justice Stone in the income tax cases.

17 Harding, op. cit. supra note 1, at p. $288 \mathrm{n}$. 134. "The tax is on incoune. I am of opinion that the rents received by appellant for the use of real estate in New Jersey may not be included in her taxable incoune. By our decisions it is established that a tax on income received for the use of land is in legal effect a tax upon the land itself. ... New Jersey, in addition to tax on the land measured by its value, may lay a tax upon the income received by the owner for its use. . . Appellant's right to own, or to collect rents in New Jersey for the use of, lands in that State was not given and is not protected by New York law. Neither of these rights is enjoyed in New York or bas any relation to appellant's privilege of residence in, or to the protection of, that state. Ability of taxpayers to pay may be taken into account for apportionment of the tax burdens that it is authorized to impose. But the financial means of those to be taxed cannot be made to generate for the state power to tax lands, or rents paid for the use of lands, beyond its borders. I would exclude the item." Butler, J., dissenting in People ex rel. Cobn v. Graves, supra note 3, at 414. 
Stripped of excess verbiage the Cohn case appears to rest on the proposition that "Neither the privilege nor the burden [of residence within the taxing state] is affected by the character of the source from which the income is derived." 18 Mr. Justice Stone envisions the income $\operatorname{tax}$ as a tax on the person measured by the income. He thus espouses a tax theory which was current in this country prior to 1903, but which has been losing ground ever since. Personal taxes measured by the value of lands are outlawed. Personal taxes measured by foreign situated chattels are outlawed. Corporate franchise taxes measured by wealth beyond the taxing power of the state have encountered difficulty. But a personal tax measured by income is said to be valid.

One should note a realgnment of cases. Maguire v. Trefry, virtually read out of the law in Senior v. Braden, reappears as a principal authority. Lawrence v. State Tax Commission emerges as a leading case. In disposing of Senior v. Braden, Mr. Justice Stone adopts a common attitude that the briefwriter in that case conceded himself out of court. ${ }^{19} \mathrm{He}$ did concede that if the tax there sought to be levied was a tax on foreign land the tax was invalid. It was the Court, however, that held that the tax there involved was a tax on foreign land from which the income was derived..$^{20} \mathrm{Mr}$. Justice Stone's explanation of Senior v. Braden appears quite different from his understanding of that case as shown by his dissenting opinion therein. ${ }^{21}$

II

At the beginning of the opinion in the Cohn case occurs a statenient which merits serious consideration. The learned Justice observes that "The stipulation of facts on which the case was tried in the state court does not indicate that appellant's income has been taxed by New Jersey." 22 How important is this? In all of the recent cases striking out duphicate ad valorem and inheritance taxes it is to be observed that the

18 Ibid. at 411 .

10 See Leland, Harding on Double Taxation (1936) 24 CaLIF. L. Rev. 379, 389-391.

20 Harding, op. cit. supra note 1 , at 300-305. One should examine Traynor, State Taxation of Trust Income (1937) 22 Iowa L. REV. 268, 268-275.

21 "The fact that it is now thought by the Court to be necessary to discredit or overrule Maguire v. Trefry, . . . in order to overturn the tax imposed here, should lead us to doubt the result, rather than the authority which plainly challenges it, and should give us pause before reading into the Fourteenth Aunendment so serious and novel a restriction on the vital elements of the taxing power." Mr. Justice Stone dissenting in Senior v. Braden, supra note 6, at 436. "The dissenting opinion of Mr. Justice Stone indicates that he understood the prevailing opimion to hold that a state could not tax the income from real property located in another state." Hubbs, J., dissenting in People ex rel. Cohn v. Graves, supra note 7, at 360, 3 N. E. (2d) at 510. "In Senior v. Braden . . . no question of the taxation of income was involved." Mr. Justice Stone in People ex rel. Cobn v, Graves, supra note 3, at 413.

22 Ibid. at 411. 
state seeking to tax had ordinary jurisdiction over the person or property involved. ${ }^{23}$ The prohibition against double taxation is a limitation upon the exercise of that jurisdiction. One must ask: Is the power of this state denied merely because the property is subject to taxation in some other place, or is the power to be denied only where it appears that the property has been taxed elsewhere? The latter may be the more accurate answer. The Court is not interested in aiding persons of wealth to escape taxation. It is interested in protecting taxpayers from burdensome and discriminatory duphicate taxation. ${ }^{24}$

A review of the basic cases limiting the taxing power of the domicil suggests that actual taxation elsewhere, as distinguished from theoretical taxabihty, is important. In Louisville \& Jeffersonville Ferry Co. v. Kentucky, ${ }^{25}$ denying the state of incorporation the power to tax a franchise right appurtenant to foreign land, it does not appear whether or not the property was actually taxed elsewhere. In the Union Transit case ${ }^{26}$, denying the state of incorporation the power to tax rolling stock permanently situated in other states, no mention of actual taxation elsewhere was made, but it is well known that many states did tax such property on a unit rule basis. The opinion speaks in terms of jurisdiction. However in Southern Pacific Co. v. Kentucky ${ }^{27}$ the Court lield that the state of incorporation could tax ocean-going vessels not shown to have acquired a taxable situs elsewhere. In Frick v. Pennsylvania, ${ }^{28}$ extending the rule of the Union Transit case to the inheritance taxation of foreign chattels, it was found that the chattels which the domicil sought to tax had already been subjected to a transfer tax in New York or Massachusetts. In Safe Deposit \& Trust Co. v. Virginia, ${ }^{29}$ denying the domicil of the cestui the power to tax his equitable interest in a trust composed of intangibles, it was shown that the entire estate had been taxed to the trustee in another state.

${ }^{23}$ Mr. Justice Holmes' now rejected tax theory was merely an effort to identify taxing jurisdiction with the definition of jurisdiction prevailing in international law. The recent cases indicate that this is insufficient, that the taxing power is related to the economic relationship between the state and the person or property taxed. HARDING, op. cit. supra note $2, \S \S 7,8$.

24 I have indicated elsewhere my belief that an important factor in these cases is the notion that while interstate investment must, like imterstate commerce generally, bear a fair share of the tax burden, such interstate imvestments are to be protected against discriminatory burdens which would tend unduly to impair the free flow of such capital. Harding, op. cit. supra note 1, at p. $286 \mathrm{n}$. 133. This factor would direct attention to actual duplicate taxation, not theoretical taxability. See Beale, Social Justice and Business Costs (1936) 49 HARv. L. REv. 593.

25 (1903) 188 U. S. 385.

26 Union Refrigerator Transit Co. v. Kentucky (1905) 199 U. S. 194.

27 (1911) 222 U. S. 63. See Brock \& Co. v. Board of Supervisors (Cal. App. 1936) 58 P. (2d) 412, aff'd. (Feb. 15, 1937) 93 Cal. Dec. 164, 65 P. (2d) 791.

28 (1925) 268 U. S. 473,42 A. L. R. 316.

29 (1929) 280 U. S. 83,67 A. L. R. 386. 
In the income tax cases the facts are similar. In Maguire v. Trefry, ${ }^{30}$ upholding a tax on income derived by a resident cestui from a foreign admimistered trust, it appeared that the statute in question expressly exempted property already taxed to the trustee. In Lawrence v. State Tax Commission, ${ }^{31}$ upholding a domiciliary income tax on income from personal services rendered in another state, no mention was made of taxation in the state in which the income was earned, but it is known that this state (Tennessee) did not have a personal income tax law in the year in question. On the other hand in Senior v. Braden, ${ }^{32}$ involving the power of the domicil to tax income from equitable interests in foreign lands, it is pointed out that the legal ownership had been taxed in full at the situs without diminution on account of any equitable interest outstanding.

The existence of actual taxation at the situs in those cases denying the domiciliary power and the absence of such a factor in those upholding the domiciliary tax may be purely fortuitous. ${ }^{33}$ But it may be signifcant. In none of the cases is it said in so many words to be a determiming factor, but in none is it dismissed as immaterial. There are of course numerous statements that the right of one state to tax is not affected by the fact of taxation elsewhere, ${ }^{34}$ but these are found in cases upholding duplicate taxation in fields then untouched by the present doctrine of "one thing, one person, one tax." These statements carry httle conviction today. ${ }^{35}$

This question then should be considered as still open. To be safe one should read the decisions in the Maguire, Lawrence, and Cohn cases as establishing for the time being no more than that the domicil may tax income from foreign situated property and from personal services rendered abroad where it does not appear that such income is already taxed at the source. So limited these cases are consistent with the ability-to-pay dognia as relied on in the opinions. Whether the broad langnage of personal taxation is to prevail must be determined at some later date.

One whose ideas of sound doctrine have received a setback at the hands of the courts may find solace in legal history. Time was when state intangibles taxes were relatively new and state inheritance tax rates in those states imposing such a tax were relatively small. Duplicate taxation was of no great national concern. During this period a strong personality

30 Supra nute 11.

31 Supra note 14.

32 Supra note 6.

33 The opinions in the state courts shed little light on this problem.

${ }^{34}$ Leading examples may be found in Blackstone v. Miller, supra note 16; Fidelity \& Columbia Trust Co. v. Louisville (1917) 245 U. S. 54; Kidd v. Alabama (1903) 188 U. S. 730; Hawley v. City of Malden (1914) 232 U. S. 1; Cream of Wheat Co. v. Grand Forks (1920) 253 U. S. 325.

35 Cases cited supra note 16. 
built up theories of taxation to sustain taxes on the same interest in two or more places. However, the volume of intangible property grew amazingly. There was more and more ownership of property across state hes. Duplicate taxation which once oppressed but a few began to burden many. Tax rates increased. Interstate investments were subject to a growing discrimination. Finally the entire structure toppled, and rules were set up to prevent taxation in more than one place.

Today state income tax laws are relatively new. Not all the states have them. The rates are relatively sinall. The volume of interstate income, because of depression conditions, has not been large. Duplicate income taxation as yet hits but few people. But soon other states will enact income tax laws. Rates are already increasing. The volume of interstate income should increase shortly. Duplicate income taxation will reach more and inore people. The resulting hampering of the free flow of capital from state to state will be of increasing national concern. The burden of duplicate incoine taxation at progressive rates may be much more onerous than duplicate intangibles taxes at flat rates. Mr. Justice Stone's categories of duplicate income taxation rest on no firmer foundation than $\mathrm{Mr}$. Justice Holnnes' categories of duphicate inheritance and intangibles taxation. If history does repeat itself, relief for the interstate investor slould lie not too far ahead. The Cohn case merely delays it.

Arthur Leon Harding.

UNTVERSITY OF IDAHO,

Moscow, IDARo. 